\title{
Qualitative Survey \& Evaluation of Urbanization and Slum Development in Ugep Urban, Yakurr Local Government Area of Cross River State, Nigeria
}

\author{
Agbor E A, Obongha U E, \& Ita E E \\ Department of Urban and Regional Planning \\ Cross River University of Technology, Nigeria
}

\begin{abstract}
The twentieth century witnessed a rapid shift in population from rural areas to urban areas in most countries of the world. There is a growing concentration of people in urban centers and Ugep in Yakurr Local Government Area of Cross River State, Nigeria, is a case study. Housing demand increases due to growth in population, rapid urbanization and industrialization. It influences quality living and its shortage more often leads to overcrowding, unsanitary conditions and slum development. The aim of this study is to assess urbanization and slum development in Ugep urban. The specific objectives include; (i) to examine the cause of urbanization and slum development in Ugep Urban. (ii) to determine the negative impact of urbanization and slum in the area under study. (iii) to make recommendations for sustainable growth and development of Ugep urban.

Field surveys and questionnaire administration were used for the collection of socio-economic data. Other methods for data collection include oral interview, direct physical observation and focused group discussion. Purposive sampling techniques was adopted and a total of 200 copies of the semi-structured questionnaire, 50 each were randomly administered in each of the four major political wards in Ugep namely, Bikobiko, Ijiman, Ijom and Ikpakapit which make up Ugep Urban. The data collected were analyzed using simple percentages and tables. The result of this study shows that Ugep urban is highly urbanized considering its increasing population in all the wards. Poverty is prevalent with a high occupancy rate. The study revealed that residents live in substandard houses without basic amenities and services. The study also revealed high incidences of criminal activities and poor health conditions due to unsanitary conditions. The study recommended the creation of employment opportunities and the provision of basic amenities and services to reduce rural-urban migration. It recommended a reduction in the cost of building materials and encouraging long-term loans with low-interest rates. The study also recommended that the Area Planning Authority in Ugep should set and enforce standards for public and private buildings and ensure that development plans obtain a building permits before structures are erected.
\end{abstract}

Keywords: Population, Socio-economic data, Slum development, Urbanization.

\section{INTRODUCTION}

Urbanization is one of the greatest phenomenon in the latter half of the $20^{\text {th }}$ century. This period witnessed a rapid increase in population from rural to urban areas in some countries of the world. Within a period of 50 years, the world witnessed a tremendous increase of urban population resulting from the growing concentration of people in the urban areas. The world urban population was 37 percent in 1970, and 50 percent by 2005. The definition of urban area differs from country to country. Most countries define urban areas based on National criteria such as population thresholds, density of residential buildings, level of public services provided, proportion of population engaged in non-agricultural world and officially designated territories, Pathak (1995). In Nigeria, an urban area is any settlement with a population of 20,000 people. In 1900, only 13 percent of the global population lived in urban areas with an increase of 29 percent and to 50 percent by the end of twentieth century (U.N. 2006).

Urbanization pattern differ between the developed and developing countries. Most people of the developed countries live in urban area compared to the majority living in the rural areas in the developing countries. Asia, Latin America and African countries have a high concentration of population living in the urban areas. South Asia for instance is more rural with lower levels of per capita income. According to the United Nations, urbanization is the movement of people from rural to urban areas with population growth which equates to urban migration. The United Nations had projected that half of the world's population would live in urban areas at the end of 2008. Though the concepts of urbanization and urban growth are interrelated processes, they differ. Urbanization is the proportion of the total population concentrated in urban settlement and is viewed as a transitional phase and a switch over from a rural economy to an industrialize society. Onyemelukwe (1977) views urbanization as a process of concentrating in large numbers or locating in an urban center or converting a rural area in tourban center. 
The United States Housing Act of 1937, defined Slum as an area where dwellings predominate which by reason of dilapidation, overcrowding, faulty arrangement of design, lack of ventilation, light or sanitation facilities or any combination of these factors is detrimental to safety, health and morals. Slum is an area and a product of blight. Blight is simply a process stage or state that characterizes a slum. In other words it describes the process by which the quality of physical development deteriorates below acceptable housing standards. A slum therefore is a cluster of structures that exhibit advanced stages of blight. Rothenberg (1967) in Okeke (2002).

A seminar in commemoration of World Habitat Day held in Enugu, Nigeria in October 1990, described slum as a squalid and decaying neighborhood, characterized by physical blight, obsolescence, extremely poor conditions of environmental hygiene and sanitation, lack of and/or inadequate basic urban infrastructure and infrastructural elements, too many people sharing a room and too many buildings for a small piece of land, high rate of social disorders, crime and prostitution, decaying properties and declining property values due to lack of maintenance, and economic distress, among other factors.

\section{RESEARCH PROBLEM}

Ugep urban in Yakurr Local Government Area of Cross River State as shown on fig. II \& III has been known as the largest native town in West Africa. It comprises of four major political wards namely, Bikobiko, Ijiman, Ijom and Ikpakapit. The population projections for Ugep urban were based on the 1963 census figure of 44,945. The projection from 1991-2011 at 3\% growth rate placed Ugep urban at 84191 people with a population density of 125.58 persons per hactre. The projected population for Ugep urban by ward at $3 \%$ growth rate from 2011-2016 is 103,220 people as shown on Table $1 \& 2$. The distribution of 2016 population for the study area is as follows - Bikobiko 28,263 people, Ijiman 25,688, Ijom 29,396, and Ikpakapit has 19,873 people respectively. Projecting the 2016 population of 103,220 figure to 2020 at the growth rate of $3 \%$ brings the current population of 116,167 people with the difference of 12,949 increase.

TABLE 1: POPULATION OF UGEP URBAN

\begin{tabular}{|l|l|l|l|l|l|l|l|}
\hline & \multicolumn{3}{|c|}{1991 POPULATION } & \multicolumn{3}{c|}{} & $\begin{array}{l}\text { Population } \\
\text { Density }\end{array}$ \\
\hline & Male & Female & Total & Male & Female & Total & \\
\hline & & & & & & & \\
\hline Ugep & 27,329 & 26,640 & 53,969 & 42,633 & 41,558 & 84,191 & 125.58 \\
\hline
\end{tabular}

Source: National Population Commission Projected Population from $1991-2011$.

TABLE 2: PROJECTED POPULATION OF UGEP URBAN BY WARD, AT 3\% GROWTH RATE

\begin{tabular}{|l|l|l|l|l|l|l|l|l|l|}
\hline & \multicolumn{3}{|c}{2011} & \multicolumn{3}{c|}{$\mathbf{2 0 1 3}$} & \multicolumn{2}{c|}{$\mathbf{2 0 1 6}$} \\
\hline Ward & Male & Female & Total & Male & Female & Total & Male & Female & Total \\
\hline Bikobiko & 12,015 & 14,689 & 26,700 & 12,375 & 15,125 & 27,501 & 12,756 & 15,506 & 28,213 \\
\hline Ijiman & 10,890 & 13,310 & 24,200 & 11,216 & 13,709 & 24,926 & 11,597 & 14,090 & 25,688 \\
\hline Ijom & 12,510 & 25,290 & 27,800 & 12,885 & 15,748 & 28,634 & 13,266 & 16,129 & 29,396 \\
\hline Ikpakapit & 8,350 & 10,205 & 18,555 & 8,600 & 10,511 & 19,111 & 8,981 & 10,892 & 19,873 \\
\hline
\end{tabular}

Source: Yakurr Leeds, 2013

This increase in the population of these political wards in Ugep urban is due to the influx of rural migrants from the neighouring communities of Yakurr Local Government Area such as Idomi, Ekori, Mkpani, Nko, Assiga, Agoi and Adim in Biase Local Government Area for employment and better living conditions. The pressure on land resources and the demand for infrastructural facilities and services to sustain the increasing population have led to urbanization and slum development in Ugep urban.

The spectacular pattern of slum development, therefore, can be assessed from the spatial expansion of the major political wards and the communities under them. Currently, Bikobiko political ward has seven (7) communities, Ijiman seven (7), Ijom eight (8) and Ikpakapit ward has eight (8) communities making a total of thirty (30) communities in Ugep urban. Slum is an area where buildings predominate which by reason of dilapidation, overcrowding, faulty arrangement or design, lack of ventilation, light or sanitation facilities or any combination of these factors is detrimental to safety, health and morals.

The UN World Habitat (1990) described slum as a squalid and decaying community, characterized by physical blight, obsolescence, extremely poor conditions of environmental hygiene and sanitation, lack of adequate basic urban infrastructure and 
infrastructural elements, too many people sharing a room and too many buildings vying for a small piece of land, high rate of social vices, crime and prostitution, decaying properties and declining property values due to lack of maintenance and economic distress among other factors. Slum buildings vary from simple shacks to permanent and well maintained structures and lacked sanitation, clean water, electricity and other basic services. More worrisome is the rate at which slum, squatter settlements and illegal structures with unsanitary conditions are springing up in Ugep and at the newly developing fringe areas of Ugep urban. There is no gainsaying the fact that residents in Ugep urban are suffering the wide array of deterioration and degradation problems in recent years.

Slum development in Ugep urban has become an issue of great concern. Building set-backs are no longer observed, no access to potable water and buildings, and distance between buildings are also no longer observed, electric cables are found running above building roofs, sanitary facilities are either not available, or where there are available they are poorly maintained. Most inner streets are untarred and narrow and those tared do not have pedestrian walk ways especially along major streets. Waste is not properly managed and disposed. Open defecation is still being experience within Ugep urban. The gully sites and drainage channels in Ugep urban present opportunities for residents within the various neighborhoods and communities to dispose their waste.

The type of housing in Ugep is a reflection of the traditional family setting, income status, social status and occupational status. The increasing population in Ugep seem to compete for limited space, accommodation and related facilities which have all depleted the aesthetics and livability in the study area.

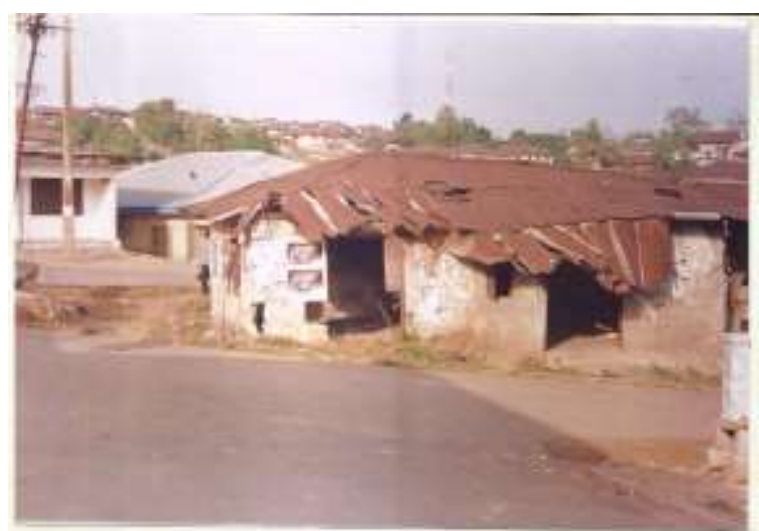

Plate 1: Overcrowding/Substandard Structures

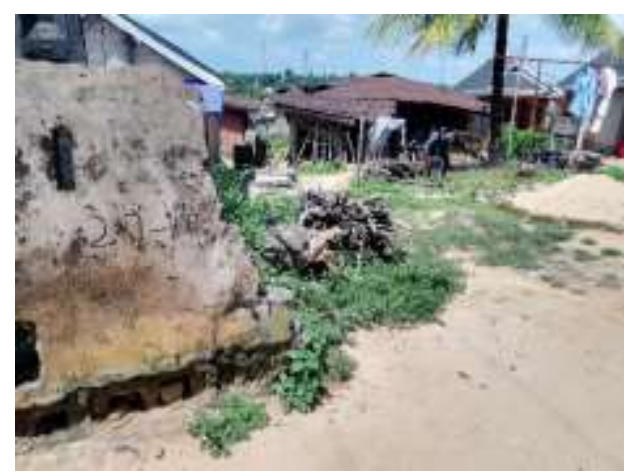

Plate 3: Substandard Houses/Environmental Decay

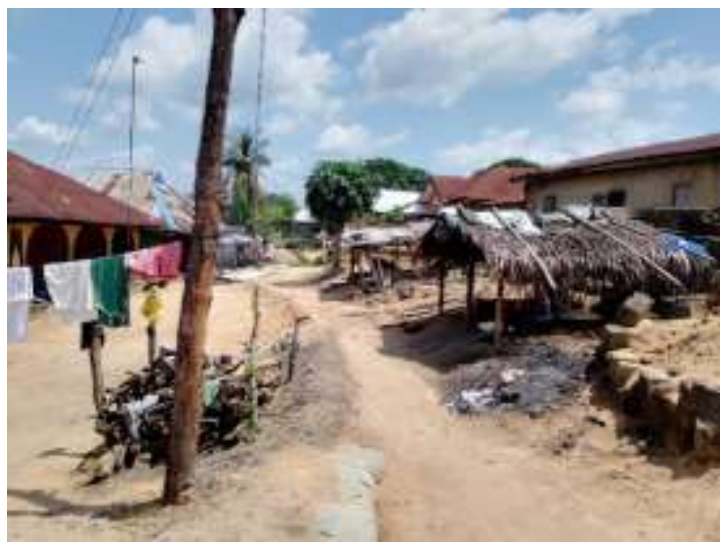

Plate 2: Narrow Untarred Street Off Obimbang Street, Bikobiko

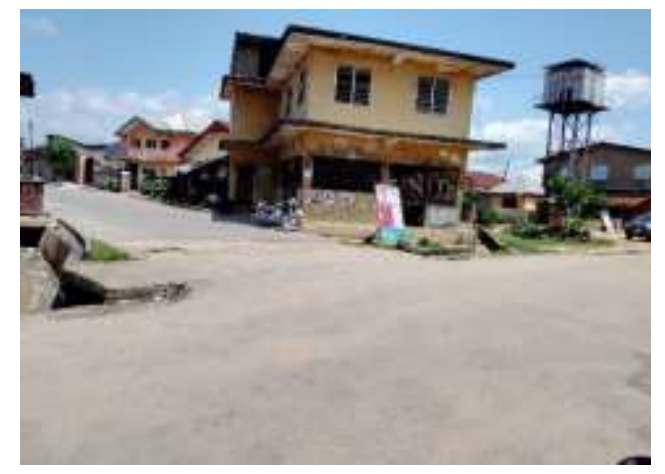

Plate 4: Poor Building Setback And Overcrowding In Ikpakapit 

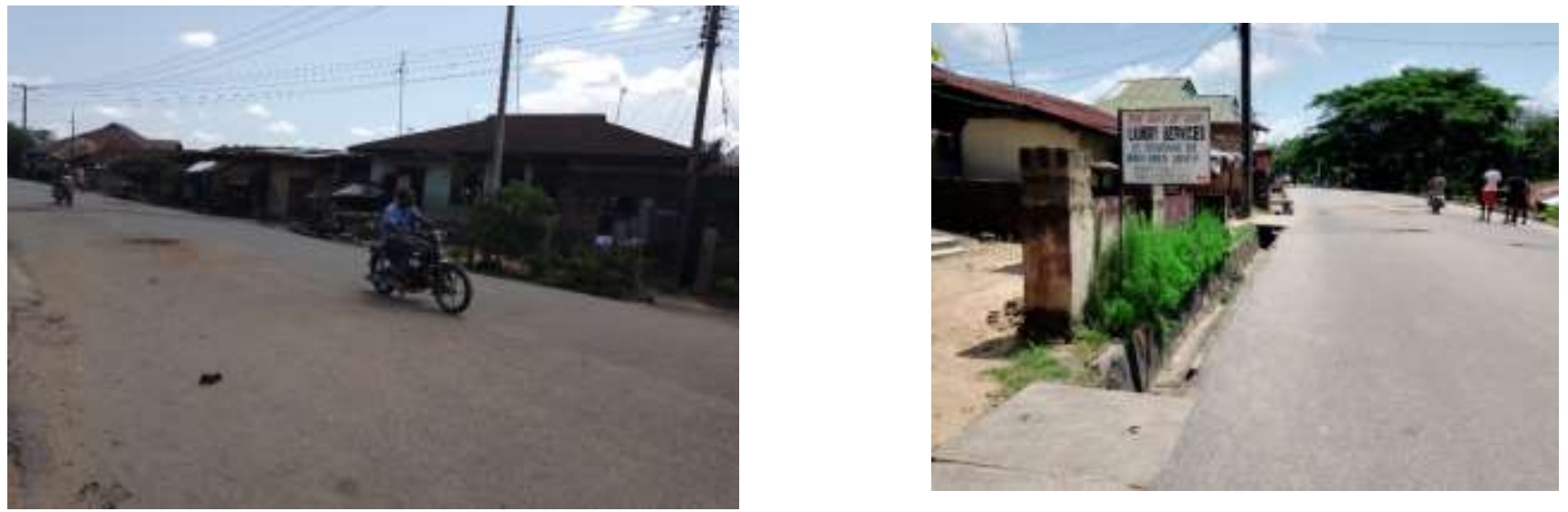

Plate 5: Buildings On Drainage Channels Along Ukpauwen In Ijiman

Plate 6: Poor Building Set-Back Along Obimbang Street, Bikobiko

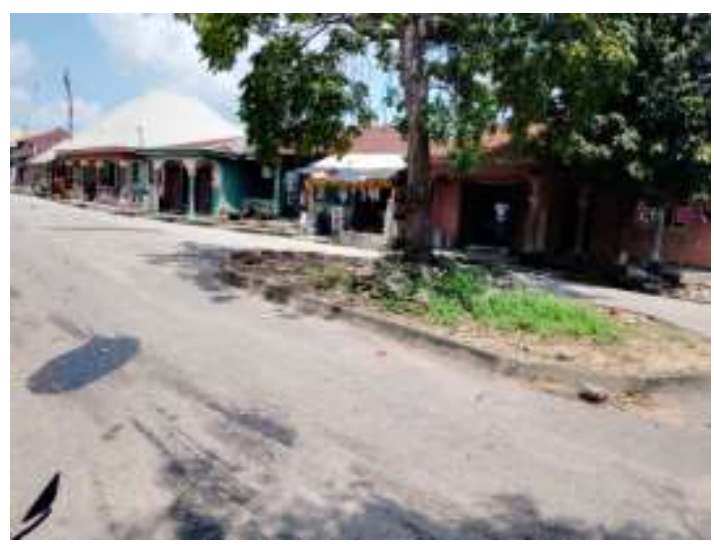

Plate7 Slum Along Akogum Street, In Ijom

\section{AIM AND OBJECTIVES OF THE STUDY}

The aim of this study is to evaluate the rate of urbanization and slum development in Ugep urban.To achieve this aim, the following objectives are stated:

i. To examine the cause of urbanization and slum development in Ugep urban

ii. To determine the negative impact of urbanization and slumin the study area

iii. To make recommendations for sustainable growth and development of Ugep urban.

\section{THE STUDY AREA}

Ugep is the administrative headquarters of Yakurr Local Government Area in the Cross River State of Nigeria as indicated in fig... 1, 2 and 3 below. Yakurr Local Government Area as shown on the Cross River State map was excised from the former Ugep Local Government Area. Yakurr is located between latitude $5^{0} 40^{\prime}$ and $5^{0} 58^{\prime}$ North of the Equator, and longitude $8^{0} 3^{\prime}$ and $8^{0} 6^{\prime}$ East of the Greenwich Meridian with a landmass of 670,4385 square kilometers. It is bounded in the North by Obubra, to the South by Biase, West by Abi and to the East by Akampka and Etung Local Government Areas. Yakurr population was 134,773 in 1991 while the official National population census was 196,450 with a population density of 126 persons per square kilometer. The Local Government Area practice nucleated settlement pattern with high population density and falls within the tropical rain forest belt. Its topography is characterized by low land and undulating landscapes. The dominant soil types are the sandy-loan and clay-loan soils which supports the cultivation of tree crops such as rubber, palm and food crops such as yams, cassava, rice, vegetables etc.

The history of Yakurr is incomplete without mention of Leboku Festival, the age long New Yam Festival "the King of crops". Leboku new yam festival is celebrated annually between the months of July and August. The people of Yakurr usually set aside 32 days for appeasing, feasting and communizing during the festival. Ugep urban which is the study has always been the conveying arena for the celebration of this ancient tradition of Leboku. (Yakurr Leeds 2013). This cultural event has permanently placed Ugep urban in the World map and attracts it large number of people each year. 
International Journal of Advances in Scientific Research and Engineering (ijasre), Vol 7 (11), November -2021

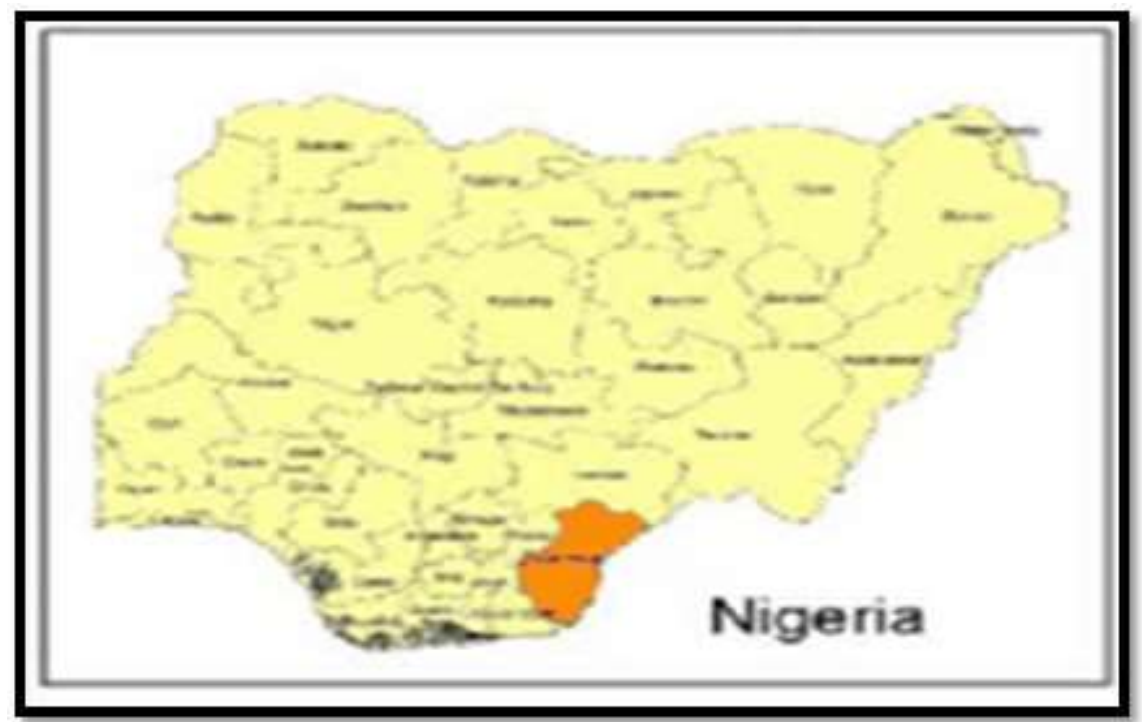

Figure 1: Map of Nigeria showing Cross River State

Source: Cross River GIA

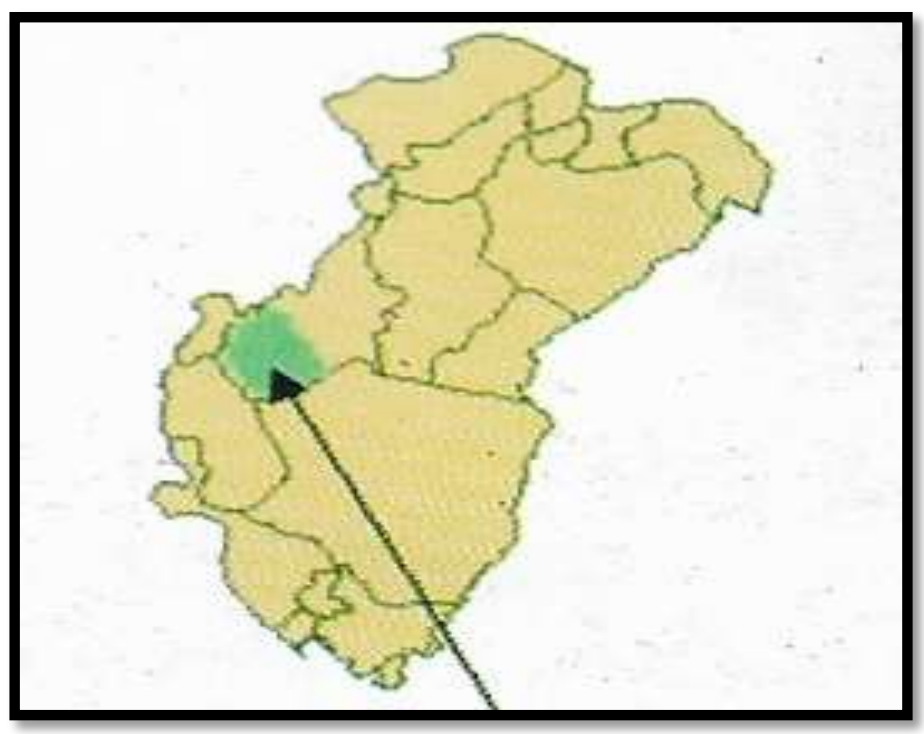

Figure 2: Map of Cross River State showing Yakurr Local Government Area Source: Cross River GIA

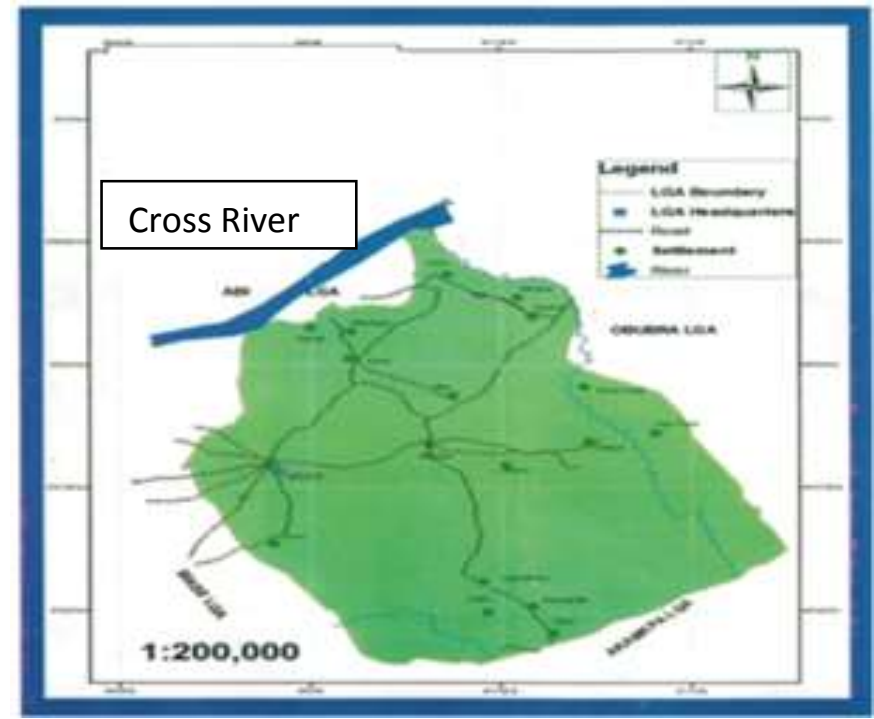

Figure 3: Map of Yakurr Local Government Area showing the study area Source: Cross River GIA 


\section{REVIEW OF LITERATURE}

\section{LITERATURE REVIEW}

Urbanization in Nigeria like most other developing countries of the world has been quite phenomenal. Nigeria which is under very intense pressure of rapid population growth and urbanization has over 5050 towns each having a population threshold of 20,000 and more located within 774 Local Government Areas in the country (Ufuoma 2001). According to Henderson (2002) the rapid urbanization over the past four decades has been accompanied by high levels of population concentrations in very large urban centres. The two major factors responsible for the increasing number of people living in urban centres and the increase in the number of towns and cities have been (1) natural population increase and (ii) the unabated influx of rural migrants into the urban centres for their wellbeing.

Knox and Pinch (2002) view urbanization as a product of rural urban migration and changing economic and social organization which has led to the rapid growth of the country's urban population.Ogunowo (2002) observed that as the urban settlements continues to grow in size and number, so is the proportion of population increase in towns and cities.Odumosu (2004) observed that apart from about ten (10) Millionaire cities (population in millions) there are 18 cities in Nigeria with population of over 500,000 people, 78 cities with over 100,000 people and 5,000 with over 20,000 people. Nigeria is among the world's 10 largest countries in population and is in the front line as one of the most rapidly urbanization countries in Africa as shown on tables 3 and 4.

Table 3: The World's 10 largest countries in population

\begin{tabular}{|l|l|l|l|l|l|}
\hline Rank & 2005 country & $\begin{array}{l}\text { Population } \\
(\text { Millions })\end{array}$ & Rank & $\mathbf{2 0 5 0}$ country & $\begin{array}{l}\text { Population } \\
\text { (Millions })\end{array}$ \\
\hline 1. & China & 1.304 & 1. & India & 1,628 \\
\hline 2. & India & 1,104 & 2. & China & 1,437 \\
\hline 3. & United States & 296 & 3. & United States & 420 \\
\hline 4. & Indonesia & 222 & 4. & Indonesia & 308 \\
\hline 5. & Brazil & 184 & 5. & Pakistan & 295 \\
\hline 6. & Pakistan & 162 & 6. & Brazil & 260 \\
\hline 7. & Bangladesh & 144 & 7. & Nigeria & 258 \\
\hline 8. & Russia & 143 & 8. & Bangladesh & 231 \\
\hline 9. & Nigeria & 132 & 9. & Dem Rep. of Congo & 183 \\
\hline 10. & Japan & 128 & 10. & Ethiopia & 170 \\
\hline
\end{tabular}

Source: PRB, 2005 Populations Data

Table 4: World population estimates and Projections for some African Countries 2000-2025 (Thousands)

\begin{tabular}{|l|l|l|l|l|l|l|}
\hline $\begin{array}{l}\text { Region or } \\
\text { country }\end{array}$ & $\mathbf{2 0 0 0}$ & $\mathbf{2 0 0 5}$ & $\mathbf{2 0 1 0}$ & $\mathbf{2 0 1 5}$ & $\mathbf{2 0 2 0}$ & $\mathbf{2 0 2 5}$ \\
\hline Africa & 821.4 & 934.3 & $1,055.7$ & $1,178.8$ & $1,304.1$ & $1,432.1$ \\
\hline Algeria & 31,399 & 34,969 & 38,397 & 41,413 & 44,255 & 47,099 \\
\hline Egypt & 62,694 & 67,713 & 72,726 & 77,340 & 81.718 & 85,940 \\
\hline Libya & 6,401 & 7,530 & 8,796 & 10,160 & 11,575 & 13,003 \\
\hline Nigeria & 127,806 & 145,646 & 164,073 & 181,649 & 199,509 & 216,900 \\
\hline Kenya & 31,409 & 35,009 & 38,484 & 41,497 & 44,404 & 47,393 \\
\hline Zaire & 50,613 & 58,856 & 67,930 & 77,371 & 87,007 & 96,568 \\
\hline Ethiopia & 66,657 & 78,368 & 91,592 & 106,312 & 122,556 & 140,008 \\
\hline S.Africa & 47,270 & 52,107 & 56,867 & 61,270 & 65,214 & 69,030 \\
\hline
\end{tabular}

Source: World population projections. A World Bank Book $1994-1995$

The United Nations (2002) observed that $40 \%$ of the population in the developing countries now live in urban areas, rising to a projected $56 \%$ by 2030 .

This unprecedented urban growth and rapid population growth have far-reaching consequences amongst which is slum development. The UN-World Habitat (1990) defines slum as a squalid and decaying community characterized by physical blight, obsolescence, extreme poor conditions of environmental hygiene and sanitation, lacking adequate basic urban infrastructural facilities, too many people sharing a room and too many buildings vying for a small piece of land, high rate of social vices, crime and prostitution, decaying properties and declining property values due to lack of maintenance and economic distress among other 
factors. Slum buildings vary from simple shacks to permanent and well maintained structures and lacked clean drinking water, electricity and other basic services. According to UN-Habitat (2007) slum is a wide range of lowincome settlements and poor human living conditions. Simply put slum is a heavily populated urban area characterized by substandard housing and squalor. The UN-Habitat (2009) further observed that many of the slum dwellers vigorously oppose the description of their committees as "slum" arguing that this results in them being pathological and others subjected to threats of evictions, yet many academics have criticized UN-habitat and the World Bank arguing that the cities without slums campaign has led directly to massive increase in forced evictions.

Fourchard (2003) identified two types of slum definitions namely "official and unofficial" slum. According to him "Official" slums are those areas that are yet to be developed in terms of good planning settlement. He noted some characteristics of official slum to include lack of infrastructural facilities, lack of layout and planning, poverty and illiteracy. He went further to describe unofficial slum as those slum areas without building plan, no good road network, lack of waste disposal, poor drainage systems, lack of pipe-borne water, overcrowding, poor sanitary condition and diseases. Abiko and Almeida (2000); Obongha and Agbor, (2020) observed that slums have over the years presented changes which have always linked to the evolution of the socioeconomic situation of their inhabitants. They further noted that slums are spontaneous housing settlements located on private or public land acquired in an illegal manner in relation to the rightful ownership of the land and whose buildings are found to be in discord with the laws of the use and occupation of land, independently of the number of building involved, or the type of house constructed. Adding that slum may be considered as one of the most conspicuous signs of the failure of our present economic and social systems.

Mabogunje (1968) describe urbanization as the process whereby human beings congregate in relatively large numbers at one particular sport of the earth's surface with consequences such as competition for land, poor transportation facilities, acute housing shortage, rapid growth of slums, poor health conditions and high rate of crime.Ogunuowo (2005) further opined that as urban areas expand, so does the extent of urban environmental impacts which manifest in the form of waste generation and management problems, housing shortages, overcrowding, slum development, poor sanitation, diverse pollution problems, and general environmental deterioration. Ebong (1980) opined that rapid population growth of many Nigeria cities do not only have impact on overcrowding but also on derelict housing and the creation of dirty and degraded environment.Ofuoma (2001), also observed that Nigeria has up to 5050 towns with each having population threshold of 20,000 or more located within 774 Local Government Areas. Egunjobi (1999) also observed that Nigeria is urbanizing with plan.

\section{CAUSES OF URBANIZATION AND SLUM DEVELOPMENT}

Rapid Population growth and urbanization are the major causes of slum development in the urban centresdue to their attendant high demand for basic services and subsequent inadequacies which exert much pressure on urban infrastructure. Other factors include rural-urban migration, economic down-turn in our urban centres and the decay of urban infrastructure and neglience of urban housekeeping, World Bank (2004). The United Nations Conference on Human Settlement (UNCHS 1981) identified other causes to include, obsence or inadequacy of periodic maintenance; poor building construction and use of substandard building materials; poor application of development control and non-compliance with building codes and town planning regulations; unauthorized change of use; multiple ownership of property; desire to maximum rent proceed and to keep maintenance cost low; absence of legal instrument or provision for property maintenance etc. Ahianba, Dimuna and Okogum (2008) also hold the opinion that shortage of urban housing, infrastructural facilities and basic urban amenities are major causes of urban slum development. These have created high demand on housing stock which leads to high rent, overcrowding and development of slums and squatter settlements.

\section{IMPACT OF URBANIZATION AND SLUMS}

The effects of slum on urban residents in both developing and the developed nations of the world include-poverty which according to the Federal Office of Statistics increased from 28.1 percent in 1980 (representing 17.1 million people) to 65.6 percent in 1996 (representing 67.1Million Nigerians) (FOS 1999). Other effects include, diseases and poor health conditions, loss of property value; fragmented families; job lost; insecurity of life and property; overcrowding of people and structures; weak tax base; high unemployment; poor aesthetic quality; dilapidated buildings (dereliction) unfriendly urban landscape; sprawl; development of squatter settlements at the urban peripheries; poor environmental hygiene; pollution (water, Air, land and noise); and lack of access to buildings (Obongha and Ukam, 2020). Residents of Ugep urban do not observe building set-backs and building lines. The result is overcrowding and poor environmental aesthetics. 


\section{METHODOLOGY}

The study is design to explore and to understand the socio-economic conditions and types of problems faced by slum dwellers and to prefer solutions for improving the quality of life of the slum dwellers in Ugep Urban. A survey design method by purposive sampling technique was adopted and a total of 200 copies of a structured questionnaire, 50 each were randomly administered in each of the four major wards namely; Bikobiko, Ijiman, Ijom and Ikpakapit which make up a total of 30 communities in Ugep urban as shown on table 5.Other methods for collection of data were oral interview, direct personal observation and focused group discussions.

Table 5: Political Wards and Communities in Ugep Urban

\begin{tabular}{|c|c|c|}
\hline $\mathbf{S} / \mathbf{N}$ & Political wards & Communities under wards \\
\hline \multirow[b]{2}{*}{2.} & Bikobiko & \begin{tabular}{|l} 
Emenko \\
Ibinda I \\
Ibinda II \\
Lebokom \\
Lekpankom \\
Njamghi \\
Niilokoko
\end{tabular} \\
\hline & Ijiman & \begin{tabular}{|l} 
Kebong \\
Lebolkotn \\
Kekpankong $\quad$ Ketankom \\
\\
Otalasi \\
Ugom \\
Utom
\end{tabular} \\
\hline \multirow[t]{3}{*}{3.} & Ijom & $\begin{array}{l}\text { Akugom Aneja } \\
\text { Kekomkolo } \\
\text { Ketababe }\end{array}$ \\
\hline & & $\begin{array}{l}\text { Lekpankom } \\
\text { Lewankom }\end{array}$ \\
\hline & & $\begin{array}{l}\text { Luseni } \\
\text { Unebu }\end{array}$ \\
\hline 4. & Ikpakapit & $\begin{array}{l}\text { Atawituen } \\
\text { Egbijom } \\
\text { Kewin } \\
\text { Letekom } \\
\text { Adayi } \\
\text { Ntankpo } \\
\text { Usaja Yenon }\end{array}$ \\
\hline
\end{tabular}

Source: Researchers Field Survey, 2021. 
International Journal of Advances in Scientific Research and Engineering (ijasre), Vol 7 (11), November -2021

9. DATA PRESENTATION AND ANALYSIS

Table 6: Socio-economic characteristics of respondents in Ugep urban

\begin{tabular}{|c|c|c|c|}
\hline 1 & $\begin{array}{l}\text { Education } \\
\text { Primary } \\
\text { Secondary } \\
\text { Tertiary } \\
\text { No formal education } \\
\text { Total }\end{array}$ & \begin{tabular}{|l} 
Frequency of response \\
52 \\
47 \\
38 \\
63 \\
200
\end{tabular} & $\begin{array}{l}\text { Percentage } \\
26.0 \\
23.5 \\
19.0 \\
31.5 \\
\mathbf{1 0 0}\end{array}$ \\
\hline 2. & $\begin{array}{l}\text { Occupation } \\
\text { Farming } \\
\text { Commerce } \\
\text { Artisans } \\
\text { Civil/Public Servants } \\
\text { Total }\end{array}$ & $\begin{array}{l}72 \\
53 \\
40 \\
35 \\
\mathbf{2 0 0}\end{array}$ & $\begin{array}{l}36.0 \\
26.5 \\
20.0 \\
17.5 \\
100\end{array}$ \\
\hline 3. & $\begin{array}{l}\text { Monthly income } \\
\text { N3000-5000 } \\
\text { N6000-8000 } \\
\text { N9000 - } 10000 \\
\text { N } 10000 \text { and above } \\
\text { Total }\end{array}$ & $\begin{array}{l}37 \\
46 \\
52 \\
65 \\
200\end{array}$ & $\begin{array}{l}18.5 \\
23 \\
26 \\
32.5 \\
100\end{array}$ \\
\hline 4. & $\begin{array}{l}\text { Household size } \\
0-2 \\
3-4 \\
5-6 \\
7-8 \\
9 \text { and above }\end{array}$ & $\begin{array}{l}20 \\
32 \\
44 \\
46 \\
58\end{array}$ & $\begin{array}{l}10.0 \\
16.0 \\
22.0 \\
23.0 \\
29.0\end{array}$ \\
\hline & Total & 200 & 100 \\
\hline
\end{tabular}

Source: Researchers Field Survey, 2021.

Table 7: Sampled type of residential housing units by ward in Ugep urban

\begin{tabular}{|l|l|l|l|l|}
\hline S/N & \multicolumn{1}{|c|}{ Ward } & \multicolumn{1}{|c|}{$\begin{array}{c}\text { No. of Block } \\
\text { Houses }\end{array}$} & $\begin{array}{c}\text { No. of Mud } \\
\text { houses }\end{array}$ & No. of Thatch Roof \\
\hline 1. & Bikobiko & 36 & 30 & 34 \\
\hline 2. & Ijiman & 28 & 38 & 34 \\
\hline 3. & Ijom & 27 & 43 & 30 \\
\hline 4. & Ikpakapit & 35 & 43 & 22 \\
\hline & Total & $\mathbf{1 2 0}$ & $\mathbf{1 6 0}$ & $\mathbf{1 2 1}$ \\
\hline
\end{tabular}

Source: Researchers Field Survey, 2021. 
International Journal of Advances in Scientific Research and Engineering (ijasre), Vol 7 (11), November -2021

Table 8: Distribution of sampled Housing facilities

\begin{tabular}{|c|c|c|c|}
\hline $\mathbf{S} / \mathbf{N}$ & Housing Facilities & $\begin{array}{l}\text { Frequency of } \\
\text { Response }\end{array}$ & Percentage \\
\hline 1. & $\begin{array}{l}\text { Water } \\
-\quad \text { Pipe borne } \\
\text { - } \text { Bore hole } \\
\text { - } \quad \text { River/stream } \\
\text { - Others } \\
\text { Total }\end{array}$ & $\begin{array}{l}10 \\
80 \\
90 \\
12 \mathbf{2 0 0}\end{array}$ & $\begin{array}{l}5.0 \\
40.5 \\
49.0 \\
6.0 \\
\mathbf{1 0 0}\end{array}$ \\
\hline 2. & $\begin{array}{l}\text { Electricity } \\
\text { - "Nepa/PCHN Electricity Agencies } \\
\text { - Generator } \\
\text { - Others } \\
\text { Total }\end{array}$ & $\begin{array}{l}80112 \\
8200\end{array}$ & $\mid \begin{array}{l}40.0 \\
56.0 \\
4.0 \\
100\end{array}$ \\
\hline 3. & $\begin{array}{ll}\text { Toilet facilities } \\
- & \text { Water Closet }(\mathrm{wc}) \\
- & \text { Pit toilet } \\
- & \text { Dump site } \\
- & \text { Bush } \\
- & \text { Drainage channels Total }\end{array}$ & $\begin{array}{l}32 \\
38 \\
42 \\
34 \\
54 \mathbf{2 0 0}\end{array}$ & $\begin{array}{l}16.0 \\
19.0 \\
21.0 \\
17.0 \\
27.0 \\
\mathbf{1 0 0}\end{array}$ \\
\hline 4. & $\begin{array}{l}\text { Waste-Disposal } \\
\text { - Open Dumping } \\
\text { - Open burning } \\
\text { - Waste bins } \\
\text { - Drainage channels Total }\end{array}$ & $\begin{array}{l}58 \\
52 \\
40,50 \\
\mathbf{2 0 0}\end{array}$ & $\begin{array}{l}29.0 \\
26.0 \\
20.0 \\
25.0 \\
100\end{array}$ \\
\hline 5. & $\begin{array}{l}\text { Lighting/Ventilation } \\
\text { - Good } \\
\text { - Fair } \\
\text { - PoorTotal }\end{array}$ & $\begin{array}{l}44 \\
63 \\
93 \mathbf{2 0 0}\end{array}$ & $\begin{array}{l}22.0 \\
31.5 \\
46.5 \\
\mathbf{1 0 0}\end{array}$ \\
\hline
\end{tabular}

Source: Researchers Field Survey, 2021.

Table 9: Types of health problems

Table 9:

\begin{tabular}{|l|l|l|l|}
\hline S/N & Disease & Frequency of response & Percentage (\%) \\
\hline & - Malaria & 6455 & 32.0 \\
& - Thyphoid & 5130 & 27.5 \\
& - Tuberculosis - & & 25.5 \\
& others & & 15.0 \\
\hline
\end{tabular}

Source: Researchers Field Survey, 2021. 
Table 10: Types of criminal activities

\begin{tabular}{|l|l|l|l|}
\hline S/N & Crime & Frequency of response & Percentage (\%) \\
\hline & - Theft & 60.52 & 30.0 \\
& - Drug usage & 43 & 26.0 \\
& - Prostitution & 37 & 21.5 \\
& - Rape & 8 & 18.5 \\
& - others & & 4.0 \\
\hline
\end{tabular}

Source: Researchers Field Survey, 2021.

\section{DISCUSSION OF FINDINGS}

Slum development in Ugep urban is constantly increasing with the lack of basic facilities which have great impact on the socioeconomic and health conditions of the residents. The study reveals that $26 \%$ of the residents have primary education while $23.5 \%$ have secondary education and tertiary having only $19 \%$ and $31.5 \%$ residents without a formal education. Education has great influence on the wellbeing of respondents in any society. The major occupation in Ugep is farming with $36 \%$ while commerce has $26 \%$, artisans $20 \%$ and civil and public servants having only $17.5 \%$.

The study also reveals that majority of the residents that is $32.5 \%$ have monthly income of less than $\$ 10,000$ and only $18.5 \%$ earn above that figure. This shows why respondents cannot live in decent environment as a result of poverty. Household size in Ugep is far above expectation with over 9 persons living in one room.

Table 7 above shows the type of residential housing units by political ward in the area of study. Housing in Ugep urban is a reflection of the traditional family setting, occupation, income and social status with the use of local building materials such as mud blocks, raffia, wood, bamboo and rafters for construction. Through group discussions the study revealed that houses plastered with cement are the most dominant housing structure spread in the various wards in Ugep urban. Through direction observation and administration of questionnaires the study revealed that most of the houses lack the basic facilities such as water, electricity, toilet facilities, waste disposals, lighting and ventilation as shown on table 8 above.

Majority of the residents in Ugep, that is, 49 percent drink from local streams and wells while 30 percent use water from the boreholes. Pipe borne water and other sources are very insignificant 10 percent and 12 percent respectively. Electricity is through the use of individual generators which is 56 percent while NEPA/PHCN is 40 percent and others 4 percent.

An interview with the staff of local government council Headquarters revealed major challenges facing waste management in Ugep urban. Among them are lack of vehicles and equipment, poor funding, skill man power, and poor attitude of residents on waste management and disposal. Dumping of waste in the open and defecation is still common in Ugep. Most residents dispose their waste in gully sites within the various neighbourhoods and communities in Ugep urban. Open burning is common and residents also dump their domestic waste into the drainage channels or gutters as indicated on table8 (4) above.

Table9 present serious health challenges ranging from diseases such as malaria, typhoid, tuberculosis, etc. stemming from poor sanitary conditions in the study area. Malaria is more prevalent with 32 percent occurrence while typhoid is 27 percent and tuberculosis having 25.5 percent and other diseases 15 percent.

The study further revealed the type of criminal activities that are associated with slum development to include theft, drug usage, prostitution, andrape, in Ugep urban. Clinard and Abbot (1973), in their study revealed a significant correlation between slum and deviant behavior.

\section{RECOMMENDATIONS}

Government at all levels should discourage rural-urban migration from the neighboring communities such as Ekori, Nkpani, Idomi, Nko etc. through the establishment of agricultural and small scale industries to provide employment opportunities for rural dwellers. They should also provide basic amenities and services and infrastructural facilities such as rural electrification, portable water, and construction of rural roads and low cost housing. They should reduce the cost of building materials and provide low interest loans to rural dwellers. The inability to meet housing need has created high demand on housing stock resulting to high rent, overcrowding and the development of slums and squatter settlements in Ugep urban. These rural migrants often exert much pressure on available urban infrastructure. 
Urban renewal approach meant to combat the deteriorating urban environment is not restricted to roads as it was done in Ugep urban in the past. It should be a continuous process of planning and rebuilding of towns and cities, sorting out uses that have become too bad and upgrading buildings, facilities and the environment to give the urban centres a useful life. This approach should be guided by the three strategies of redevelopment, rehabilitation and conservation

The Federal and State Governments should approach World Bank, UNICEF, Non-governmental Organizations Financial Institutions and other charitable institutions to finance housing schemes for the urban poor. Urban land ceiling plans should be enforced to regulate the prices of urban land. Plots of land should be provided and long-term loans with low interest rates, and subsidies should be encouraged by both the public and private sectors. Low-cost houses should be designed and constructed with standard and cheap building materials. Programmes aimed at improving the income of the poor urbanites such as job training and micro-enterprise development should be encouraged. Basic civic amenities like clean drinking water, sanitation education and good health-care facilities and security should be provided for peaceful and safety living conditions. Industrial and domestic waste should be properly managed and disposed. The Ugep urban master plan should be reviewed by the state government and strictly enforced to avoid undesirable urban growth and development.

The Area Planning Authority (APA) in Ugep urbanshould set and enforce standards for public and private buildings and ensure that all development plans are duly approved and granted building permits before structures are erected. Staff of the planning authority should also ensure that provision is made by the architect for proper ventilation in buildings. Building lines as well as distances or setbacks between buildings should strictly be enforced. Maximum building heights should be enforced and easy access provided to houses as most buildings in Ugep urban have no access except narrow foot paths, as shown on plate 2 above.

\section{CONCLUSION}

The resent trend in urbanization and slum development has shown that cities are rapidly expanding beyond their boundaries. Land is a scarce resource and an essential ingredient for urban growth yet most urban areas have virtually no effective measures to control land development and slums. Ugep urban as a case study does not have enough land for future development hence the frequent conflicts with her neighbouring communities of Adim, Idomi, Ekori and Mkpani. The primary objective of government at all levels is to create better employment opportunities and providing basic amenities and encourage agricultural and small scale industries at the rural areas to reduce the rural migrants to urban centres. Urban renewal projects should go beyond rehabilitation of roads to slum clearance, and conservation to improve the quality of life of residents. Non-Governmental Organization (NGOs) must play an important role in the development process.

The town planners and policy makers should take up the challenges of devising equitable land development policies and effective land development control mechanism to curb the incidence of slum development in Ugep urban as a case study and other urban centres in Cross River State, Nigeria.

\section{ACKNOWLEDGEMENTS}

We want to sincerely appreciate all the Authors whose materials had been used as referenced in the bibliography page. We also want to thank our spouses and children for the time spent while carrying out this research and finally, the Cross River University of Technology for creating enabling environment as our workplace in which this research was carried out. Above all, we give glory to God Almighty for life, knowledge and wisdom.

\section{REFERENCES}

1. Abiko, A.K. and Almeida MAP.(2002) Environmental Sanitation Indicators for upgraded slums ; The case of Jarcim Floresla slum (Favela) in the city of Sao Paulo.

2. Agbola, T. and Agunbiade, E. M. (2007) I'roan slum development and security of tenure: The challenges of meeting Millenium Development Goal (MGD) in Metropolitan Lagos, Nigeria.

3. Akin L. Mabogunje (1968): Urbanization in Nigeria University of London Press Ltd.

4. Ahianba, J. E; Dimuna K 0; and Okogun G. R.A. (2002) Built Environmental Decay and Urban Health in Nigeria: Published by Ambrose Ali University, Ekpoma, Nigeria. 
5. Egunjobi, Layi (1999): "Our Gasping cities". Inaugural lectures University of Ibadan, Ibadan University Press, Thursday 21 th October.

6. Fourchard, L.(2003) Overview of Nigeria economic and social trends in the $20^{\text {th }}$ century. The case of Ibadan, Nigeria. Published by Laurent Fourchard Institute Francasi de Recheche en Ajrique (IFRA), University of Ibadan, Nigeria.

7. Henderson, V. (2002):"Urbanization in Decaying countries". The world Bank Research Observer, Vol. 17(1) (Spring).

8. Knox, P. and Pinch, S.(2000). Urban Social Geography; An introduction, Essex, Pearson Publication Limited.

9. Local Economic Empowerment and Development Strategy (2016) Yak-LEED 2.

10. Ministry of Lands, Surveys and Urban Development, Calabar, Cross River State, Nigeria. Final Master Plan for the Divisional Headquarters of Obubra, September 1977.

11. Nigerian National Population Commission (1963).

12. Obongha, U. E. and Agbor, E. A. (2020). Challenges Facing London's Urban Development in a Globalizing World. Journal of social and Environmental Sciences 2 (1): 9-15.

13. Obongha, U. E. and Ukam, L. E. (2020). The Impact of settlement pattern of some Nigerian cities on the spread Covid-19 Pandemic. European Journal of Environment and Earth Sciences 1 (4): 1-6.

14. Odumosu, Tayo (2004): The Catalo-Reactant of Development. Urbanization Through the Age. Inaugural lecture. Lagos State University (LASU), Lagos Free Enterprise Publishers, Thursday $11^{\text {th }}$ March.

15. Ogunnowo, C. O. (2002): "Towards Enhancing Food Security in Nigeria Urban centres in the $21^{\text {st }}$ century." The Beacon (Journal of TASCE) Vol. 5 (1) April Pp 43-53.

16. Okeke, D. C. (2002) Environment and urban renewal strategies: Theoretical and Analytical Frameworks. Published by institute for development studies, University of Nigeria, Enugu Campus, Nigeria.

17. Ufuoma, P. (2001): "Nigeria to Host Global Campaign on Urban Governance"The Punch Monday, $16^{\text {th }}$ April, R23 United Nations (2002). World Urbanization Prospects: 'The 2001 Revision". Population Reports.Vol.30 (4) (Fall) Series M. No.1 GpgS.

18. UN-HABITAT (2007): Sustainable Urbanization: Local Action Urban poverty production; Emphasis on finance and Planning: The $21^{\text {st }}$ Session of the Governing Council United Nations.

19. UN-Habitat (2009): Urban Indicators guidelines: Monitoring the Habitat Agenda and the Millenium Development Goals Slum Target

20. UN-World Habitat Day October (1990) Seminar, Enugu, Nigeria.

21. World Population Projections: World Bank Book (1994-1995)

Corresponding email: ukpalieze@ crutech.edu.ng 